\title{
Impact of monsoonal rains on spatial scaling patterns in water chemistry of a semiarid river network
}

\author{
Vicenç Acuña ${ }^{1}$ and Clifford N. Dahm ${ }^{2}$ \\ Received 22 May 2007; revised 3 August 2007; accepted 27 August 2007; published 1 December 2007.
}

[1] The chemical composition of surface waters of nine streams with drainage sizes ranging from 44 to $8900 \mathrm{~km}^{2}$ within a semiarid catchment in the southwestern United States was examined over the monsoonal season of 2006. Primary goals were to determine the impact of monsoonal rains on linkages between landscape cover features and water chemistry in a semiarid river network and to identify whether drainage size influences the temporal variability in water chemistry of streams. Landscape cover features (geology, soil, and vegetation types) were quantified for the subcatchment upstream of each study site and the riparian ecotone. Processes of binary mixing, dilution, and concentration were identified by end member mixing analysis (EMMA). Results showed that most chemical constituents corresponded to geological features at the basin scale, but other constituents (TSS and $\mathrm{PO}_{4}^{3-}$ ) corresponded more closely to riparian features. Importantly, statistical relationships between land cover and water chemistry differed between baseflow and monsoonal conditions, suggesting that seasonal changes in hydrologic routing and water sources (e.g., overland flow versus groundwater sources) have important consequences for stream chemistry. In contrast with mesic drainages, temporal variability in water chemistry increased with spatial scale. The variety of contributing water sources and the relative effect of dilution and concentration in each spatial scale may be underlying processes that explain differences across spatial scales. Observed patterns in the Gila basin suggest that climate variability interacts with hydrologic routing to influence spatial patterns of stream water chemistry in arid basins. Observations made here may be similar to other systems with strongly seasonal climate patterns, and the underlying determinants of stream chemistry change with drainage size.

Citation: Acuña, V., and C. N. Dahm (2007), Impact of monsoonal rains on spatial scaling patterns in water chemistry of a semiarid river network, J. Geophys. Res., 112, G04009, doi:10.1029/2007JG000493.

\section{Introduction}

[2] Variation in surface water chemistry within and between aquatic ecosystems is regulated by factors operating at multiple spatial and temporal scales. Hynes [1975] first addressed the terrestrial-aquatic linkage concept, where streams are regarded as open systems intimately linked with their surrounding landscapes. Indeed, the surrounding landscape with its distinct geology, hydrology, vegetation and climate clearly influences the physical, chemical and biological features of stream ecosystems [e.g., Allan, 1995; Allan and Johnson, 1997; Johnson et al., 1997; Stutter et $a l ., 2006]$. The chemical composition of streams is thought to be driven by factors acting at both catchment and riparian-ecotone scales. Catchment-scale features such as geology and weathering are interrelated with other factors such as soil type and land cover, whereas riparian-ecotone factors, like the input of organic matter, are related to local

\footnotetext{
${ }^{1}$ Department of Aquatic Ecology, Eawag, Dübendorf, Switzerland.

${ }^{2}$ Department of Biology, University of New Mexico, Albuquerque, New Mexico, USA.

Copyright 2007 by the American Geophysical Union. 0148-0227/07/2007JG000493
}

vegetation type and topography. In addition to diverse spatial linkages that operate between terrestrial and aquatic ecosystems, stream water chemistry is also affected by temporal changes in the sources of water. Water originating as surface runoff and derived from groundwater reservoirs is mixed in streams in continuously changing proportions. During periods of low rainfall, streams carry primarily groundwater whose chemical composition depends on the geology of the catchment. During rainy seasons, surface runoff dominates and may result in changes to the chemical makeup of stream water [Faure, 1998].

[3] Previous research by stream ecologists has focused on assessing land use effects on surface water chemistry, especially assessing urban and agricultural effects on nutrient and/or dissolved organic carbon concentrations [e.g., Peterjohn and Correll, 1984; Hunsaker and Levine, 1995; Allan et al., 1997; Johnson et al., 1997; Gergel et al., 1999]. Few studies, however, have addressed the temporal variability in stream water chemistry within catchments across spatial scales [see Stutter et al., 2006; Stendera and Johnson, 2006; Buffam et al., 2007]. Stutter et al. [2006] studied the link between the spatial distribution of soils and the heterogeneity of surface water chemistry in a small granitic 
upland catchment (NE Scotland), and showed that mean chemical composition at the catchment outlet showed lower temporal variability compared to headwater sites. Indeed, several studies in mesic catchments have found that temporal variability in stream water chemistry decreases in a downstream direction [Temnerud and Bishop, 2005; Stutter et al., 2006]. There are a variety of processes that may contribute to longitudinal changes in the chemical composition of streams, but the overriding factor that reduces variability as catchment size increases is thought to be the mixing of different water sources with downstream position in the network [Temnerud and Bishop, 2005; Stutter et al., 2006].

[4] In regions with strongly seasonal precipitation regimes, abrupt changes in precipitation frequency and intensity may have profound effects on stream chemistry by altering the contribution of different water sources, and increasing the concentration of suspended sediments delivered via overland flow. The monsoon season in the southwestern United States is an example of this kind of hydrologic setting. The North American monsoon is a regional atmospheric circulation pattern that controls the magnitude and frequency of summer rainfall from convective thunderstorms in northwestern Mexico and southwestern United States [Douglas et al., 1993; Adams and Comrie, 1997; Sheppard et al., 2002], and is experienced as a pronounced increase in rainfall from an extremely dry June to a rainy July. Rains typically last until mid-September, when a drier regime is reestablished over the region [Adams and Comrie, 1997]. Indeed, there are other systems not associated with monsoons but potentially with hydrological patterns similar to those observed in the southwestern United States, like Mediterranean regions with dry summers and wet fall and spring seasons.

[5] This paper presents water chemistry data from a semiarid catchment in the southwestern United States (the upper Gila River), and examines the impact of monsoonal rains on water chemistry of streams at different spatial scales (spatial scale refers to increasing drainage area) within the same catchment. The objectives of this study were to determine the impact of monsoon rains on linkages between landscape cover features and the chemical composition of streams in a semiarid river network and to characterize temporal patterns of water chemistry among drainage units of increasing area. Processes operating at spatial scales ranging from local to regional are affected by human activities, and a better understanding of these scaledependent processes is fundamental to sound management of freshwater ecosystems [Allan and Johnson, 1997]. A better understanding of headwater systems in arid and semiarid lands is also necessary because of increasing conflicts between sustaining ecosystem services and meeting human demands for water, coupled with the susceptibility of semiarid lands to environmental deterioration due to climate change.

\section{Site Description}

[6] The study was conducted in the Gila River network (Figure 1). The Gila River is a tributary to the Colorado River and rises in the Mogollon Mountains of southwestern New Mexico (United States). The study area drains 8900 $\mathrm{km}^{2}$ of the headwaters of the Gila River, where the river is among the few free-flowing rivers left in North America.

[7] Climate in the study area ranges from arid to subhumid. Average annual rainfall ranges from $231 \mathrm{~mm}$ in the lowlands to $1000 \mathrm{~mm}$ in the peaks of the Mogollon Mountains (National Climatic Data Center). During the monsoon season, the climatological low-level atmospheric flow has a southerly component, transporting moisture into this arid region and accounting for a large percentage $(\sim 30-70 \%)$ of the total annual precipitation between July and September [Douglas et al., 1993; Sheppard et al., 2002].

[8] High plateaus and deep canyons of the MogollonDatil volcanic field dominate the entire study area. Elevation of the Datil-Mogollon section ranges from $3320 \mathrm{~m}$ at Whitewater Baldy in the Mogollon Mountains to $1463 \mathrm{~m}$ at the Gila River Valley. The two major land cover categories in the Gila River catchment are extensive forest areas at higher elevations and rangeland in most of the rest of the catchment. Small urban and agricultural communities are only present along the lower river valley in the Gila-Cliff area. Lithostratigraphic units in the Gila River catchment range in age from Quaternary to Precambrian. Upper Cenozoic basin fill of the Gila Group and local basalts comprise the most extensive aquifer in the Gila River catchment. An important, but areally limited, aquifer unit is the inner valley fill of the Gila River Valley and the major perennial to intermittent tributaries.

\section{Methods}

\subsection{Subcatchment Selection and Site Location}

[9] Surface water physico-chemical parameters and stage were measured in 9 sites within the Gila River network before, during, and after the monsoon season of 2006. These sites were chosen to reflect different spatial scales within the same catchment. A unique subcatchment was delineated for each site and a suite of catchment characteristics was incorporated into a geographical information system (GIS) database. Catchments varied in size from 44 to $8900 \mathrm{~km}^{2}$ (Figure 1); rivers ranged from third to seventh order (geomorphic definition).

\subsection{Sampling Methods}

\subsubsection{Hydrology}

[10] Water level was monitored continuously at all sites from May 2006 to December 2006 using pressure transducers (Solinst Levelogger Gold Model 3001 and Solinst Barologger Gold Model 3001, Solinst Ltd, Georgetown, Canada). Discharge data were obtained from two USGS gauging stations, one on the Gila River (USGS 09430500) and one at Mogollon Creek downstream of the confluence with Rain Creek (USGS 09430600). Discharge was used when available and water level as a surrogate when not available.

\subsubsection{Surface Water Chemistry}

[11] Water samples were collected in triplicate every two weeks from May to December 2006, filtered in situ through glass fiber filters (Whatman $\mathrm{GF} / \mathrm{F}$ ), placed in prerinsed polyethylene bottles and stored at $4{ }^{\circ} \mathrm{C}$ while being transported to the laboratory for analysis. Physico-chemical parameters analyzed were major anions $\left(\mathrm{Cl}^{-}, \mathrm{Br}^{-}, \mathrm{PO}_{4}^{3-}\right.$, 


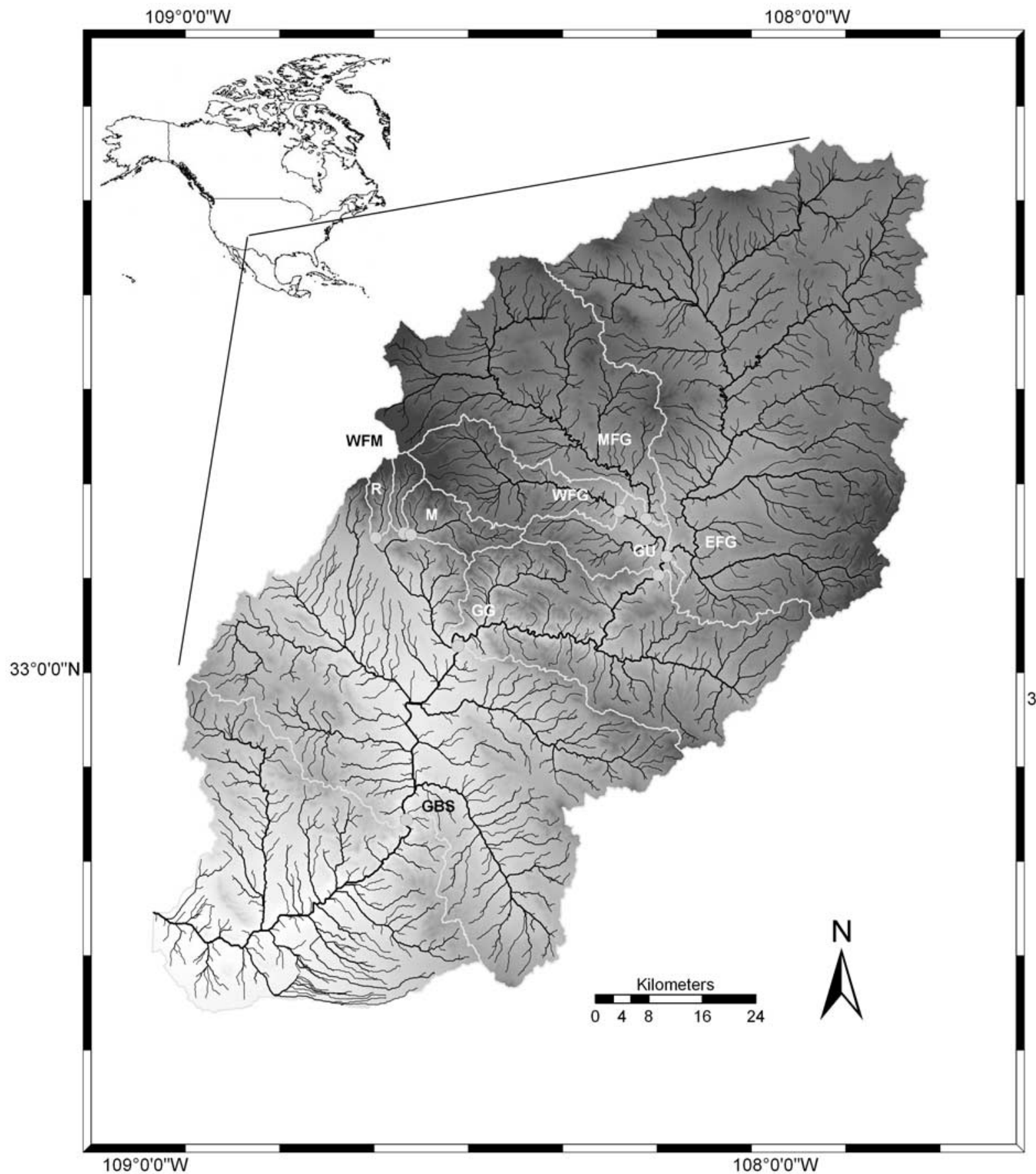

Figure 1. Study sites and subcatchments within the Gila River catchment in the southwestern United States (note acronyms in Table 1).

$\mathrm{NO}_{3}^{-}, \mathrm{SO}_{4}^{2-}$ and $\left.\mathrm{HCO}_{3}^{-}\right)$, major cations $\left(\mathrm{Ca}^{2+}, \mathrm{Mg}^{2+}, \mathrm{K}^{+}\right.$, and $\mathrm{Na}^{+}$), $\mathrm{NH}_{4}^{+}$and total suspended solids (TSS). Anions were analyzed using a Dionex Ion Chromatograph (Dionex Corp., Sunnyvale, United States) following standard procedures $[A P H A, 1998]$, while cations were analyzed by inductively Coupled Plasma-Atomic Emission Spectrometry using an Optima 5300 DV (Perkin Elmer, Waltham, United States) and following standard methods [APHA, 1998]; $\mathrm{NH}_{4}^{+}$was analyzed using a Technicon AutoAnalyzer II (Technicon Instruments Corp., Middletown, United
States), also following $A P H A$ [1998]. Data are reported as instream concentrations, which have been shown to be more appropriate than loads for catchment water chemistry studies [Osborne and Wiley, 1988]. Water samples were also collected at 11 sites along the main stem of the Gila River during baseflow and during high flow conditions to identify processes of mixing, dilution or concentration along the Gila River. Ionic concentrations were transformed to milliequivalent percentages among cations and among anions and plotted on a Piper diagram. Piper diagrams characterize 
Table 1. Landscape Variables Used to Describe Influences on Chemical Composition of Streams

\begin{tabular}{|c|c|c|}
\hline & Feature & Feature \\
\hline \multicolumn{3}{|c|}{ General Descriptors } \\
\hline Drainage size $\left(\mathrm{km}^{2}\right)$ & Average elevation & Average precipitation \\
\hline Stream order (Strahler) & Average slope & \\
\hline \multicolumn{3}{|c|}{ Vegetation } \\
\hline$\%$ Chihuahuan Desert Scrub & \% Juniper savanna & \% Plains-mesa grassland \\
\hline$\%$ Closed basin scrub & $\%$ Montane coniferous forest & $\%$ Sub-alpine coniferous forest \\
\hline$\%$ Coniferous and mixed woodland & $\%$ Montane grassland & \\
\hline$\%$ Desert grassland & $\%$ Montane scrub & \\
\hline \multicolumn{3}{|c|}{ Geology } \\
\hline$\%$ Upper Cretaceous rocks & $\%$ Mississippian and Devonian rocks & $\%$ Lower middle Tertiary pyroclastic rocks of the Datil group \\
\hline$\%$ Permian rocks & $\%$ Basaltic to andesitic lava flows & $\%$ Tertiary intrusive rocks of intermediate $\mathrm{Si}$ composition \\
\hline$\%$ Paleozoic rocks & $\%$ Piedmont alluvial deposits & $\%$ Lower middle Tertiary andesitic to dacitic lavas \\
\hline$\%$ Gila group, conglomerate & $\%$ Silurian and Ordovician rocks & $\%$ Lower middle Tertiary rhyolitic lavas \\
\hline$\%$ Alluvium & $\%$ Tertiary-Cretaceous intrusive rocks & $\%$ Upper middle Tertiary rhyolitic lavas \\
\hline$\%$ Silicic volcanic rocks & $\%$ Andesite of the Mogollon group & $\%$ Upper middle Tertiary pyroclastic rocks of the Mogollon group \\
\hline$\%$ Eolian deposits & $\%$ Upper middle Tertiary volcanic rocks & $\%$ Tertiary-Cretaceous andesitic to dacitic lavas \\
\hline$\%$ Mancos Shale & & \\
\hline \multicolumn{3}{|c|}{ Soil } \\
\hline$\%$ Aquic Ustifluvents & $\%$ Fluventic Ustochrepts & $\%$ Typic Eutroboralfs \\
\hline$\%$ Aridic Argiborolls & $\%$ Lithic Argiustolls & \% Typic Haplustalfs \\
\hline$\%$ Aridic Istochrepts & $\%$ Lithic Ustochrepts & $\%$ Udic Ustochrepts \\
\hline$\%$ Cumulic Haplustolls & $\%$ Mollic Eutroboralfs & $\%$ Ustollic Haplargids \\
\hline$\%$ Eutric Glossoboralfs & $\%$ Typic Argiborolls & \\
\hline
\end{tabular}

the relative concentration of multiple solutes, and are commonly used for geochemical classification of natural waters and interpretation of chemical data [Faure, 1998].

\subsubsection{Landscape Features}

[12] Land cover (types of soil and vegetation), surficial geology, catchment area, mean catchment elevation and mean catchment precipitation were used to quantify different aspects of landscape structure (Table 1). Data for the study area were obtained from the New Mexico Resource GIS Program. The geological information is based on 1:500,000 geological maps of 1994, the vegetation is based on 1:1,000,000 vegetation maps of 1991, and the soils are based on 1:250,000 maps of 1994. The delineation of catchment and subcatchment boundaries was based on a 90-m Digital Elevation Model (DEM). Then, knowing elevation and applying the rule that water flows in the direction of the steepest downhill gradient, flow direction, flow lengths, slopes, drainage area and subcatchment boundaries were inferred. All databases were projected onto a common coordinate system and analyzed in ArcGIS 9.1 (ESRI, United States) as vectors. Buffer analysis was used to extract landscape data from a region $100 \mathrm{~m}$ on each side of the river [Osborne and Wiley, 1988; Richards and Host, 1994; Richards et al., 1996; Johnson et al., 1997]. This procedure allowed a comparison of landscape descriptors within the river corridor with data derived from the entire subcatchment. Identical analyses were performed on both the riparian ecotone and subcatchment data to determine relationships between landscape features and surface water chemistry.

\subsubsection{End Member Mixing Analysis (EMMA)}

[13] Temporal variation in the concentration of conservative elements is caused by mixing of two or more components of water, by ion-exchange equilibria, and by evaporative concentration [Faure, 1998]. Differentiating the origins of catchment waters using natural tracer end member compositions for components of flow is a common hydrochemical technique [e.g., Burns et al., 2001; Bernal et al., 2006]. EMMA models were developed according to the procedure outlined by Christophersen et al. [1990], using $\mathrm{Cl}^{-}, \mathrm{Br}^{-}$and $\mathrm{SO}_{4}^{2-}$ as conservative tracers to identify processes of mixing between two or three water sources and processes of concentration and dilution along the river network. Proportions of water originated at each water source were estimated using:

$$
\left[\mathrm{Cl}^{-}\right]_{\text {stream }}=\left[\mathrm{Cl}^{-}\right]_{A} f_{A}+\left[\mathrm{Cl}^{-}\right]_{B}\left(1-f_{A}\right)
$$

where $\mathrm{A}$ and $\mathrm{B}$ are two components (end members) of different chemical composition and $\mathrm{f}_{\mathrm{A}}$ is a dimensionless number constrained between zero and unity. Although $\mathrm{S}$ is a macronutrient, $\mathrm{SO}_{4}^{2-}$ was considered a conservative solute because of high concentrations relative to the potential biotic demand in the soils of the riparian forests, as well as the low likelihood of sulfate reduction along the channel. Chemical data on feasible water sources were obtained from the National Atmospheric Deposition Program (NM01 Gila Cliff Dwellings) for meteoric water and from Witcher (personal communication) for geothermal springs. The $\mathrm{Cl}: \mathrm{Br}$ ratio was used to identify the feasible influence of geothermal springs. The $\mathrm{Cl}: \mathrm{Br}$ ratio of geothermal waters is influenced by enrichment in $\mathrm{Cl}^{-}$. Therefore, $\mathrm{Cl}: \mathrm{Br}$ ratios are greater than $\sim 1500$ for geothermal springs (Crossey, personal communication).

\subsection{Data Analysis}

[14] Normality of all variables was assessed and appropriate transformations were applied to non-normal variables. Descriptive statistics were calculated for the databases of surface water chemistry and landscape features. Bivariate regression analyses were used to explore the potential influence of landscape cover features, characterized at 


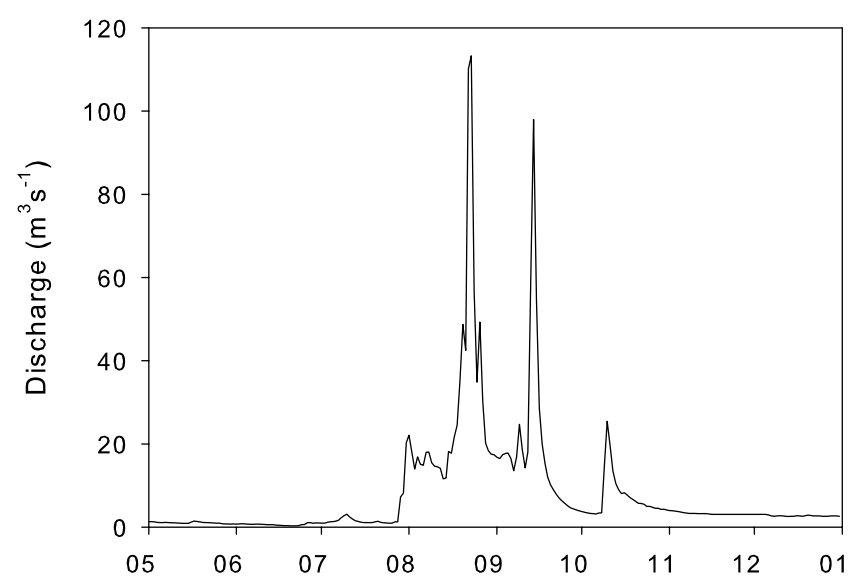

Figure 2. Discharge in the Gila River from 1 May 2006 to 1 January 2007. Conditional data obtained from USGS gauging station USGS 09430500.

subcatchment and riparian scales, on surface water chemistry. These analyses were completed for baseflow (1 May to 25 July and 15 October to 31 December) and monsoon dates (26 July to 15 October), as well as with the average values of all sampling dates. A paired-samples $\mathrm{T}$ test was used in order to determine when the connection between landscape cover features and water chemistry was stronger. Thus, the correlation coefficients between landscape cover features and surface water chemistry obtained during baseflow $\left(\mathrm{R}_{\text {baseflow }}\right)$ or monsoon dates $\left(\mathrm{R}_{\text {monsoon }}\right)$ were contrasted by means of the paired-samples $\mathrm{T}$ test. This procedure computes the differences between values of the two variables $\left(\mathrm{R}_{\text {baseflow }}-\mathrm{R}_{\text {monsoon }}\right)$ for each case (solutes) and tests whether the average differs from 0 . Simple linear regression analyses and the paired-samples $\mathrm{T}$ test were performed with SPSS 14.0 (LEAD Technologies Inc., United States). Bivariate regression was also used to evaluate the relationships between discharge and water chemistry at each site. Correlation analyses between conservative solutes were performed to identify mixing, dilution or concentration processes as described above in the EMMA section.

[15] A Principal Component Analysis (PCA) was performed with the surface water chemistry to reduce the number of dependent variables aiming to evaluate spatial and temporal variability in stream water chemistry using a single metric. Factor loadings of the first principal component were extracted without rotation and used for further regression analysis. PCA analysis was performed with SPSS 14.0 (LEAD Technologies Inc., United States). PCA is useful for data reduction and to assess the continuity/overlap of clusters or clustering/similarities in the data, but does not provide information on the chemistry of the statistical groups. The combination of graphical (e.g. Piper diagrams) and statistical (e.g. PCA) techniques provides a consistent and objective means to classify large numbers of samples while retaining the ease of classic graphical representation.

\section{Results}

\subsection{Climatology}

[16] In June 2006, the monsoon involved a rapid shift in rainfall from an extremely long drought, which lasted from November 2005, to a very rainy July 2006. Monsoonal rains lasted until late September, when a drier regime was reestablished over the study area. The monsoonal rains of 2006 were considerably higher than average, so that rainfall between 1 July and 30 September was $298 \mathrm{~mm}$ in 2006, while the average of the last 11 years was $184 \mathrm{~mm}$. Monsoonal rains produced an above average discharge, so that total discharge between 1 July and 30 September was $132.6 \mathrm{hm}^{3}$ in 2006 , while the average of the last 11 years was $33.6 \mathrm{hm}^{3}$ (Figure 2).

\subsection{Surface Water Chemistry}

[17] Average major ion concentrations ranged over one order of magnitude and did not differ from the World average of unpolluted rivers. However, the larger streams showed higher concentrations, particularly for $\mathrm{Ca}^{2+}, \mathrm{Mg}^{2+}$, $\mathrm{Na}^{+}$and $\mathrm{SO}_{4}^{2-}$ (Table 2). The Piper diagram shows that surface waters in the Gila River network can be classified as mixed cations to alkali (Figure 3a) and bicarbonate rich (Figure 3b). In the Gila, surface water chemistry was dominated by $\mathrm{Ca}^{2+}$ and $\mathrm{HCO}_{3}^{-}$, but the $\mathrm{Na}^{+}$concentrations were relatively high and did not have a counterpart with $\mathrm{Cl}^{-}$ (Table 1). Study sites draining the Mogollon mountain range showed a clear dominance by $\mathrm{HCO}_{3}^{-}(>80 \%)$ (Figure $3 \mathrm{~b}$ ). The majority of study sites were most likely $\mathrm{N}$ limited, with inorganic $\mathrm{N}: \mathrm{P}$ ratios averaging 8.8. However, the largest system (GBS) (see Table 2 for acronym definition) was likely $\mathrm{P}$ limited, with inorganic N:P ratios averaging 24.7 .

\subsection{Spatial Variability in Surface Water Chemistry}

[18] Drainage size and geological land cover features at the subcatchment scale explained a majority of the variabil-

Table 2. Average and Standard Deviation of Chemical Composition of Study Sites in the Gila River Network and of Major Rivers of the World $^{\mathrm{a}}$

\begin{tabular}{|c|c|c|c|c|c|c|}
\hline River & $\mathrm{Ca}^{2+}$ & $\mathrm{Mg}^{2+}$ & $\mathrm{Na}^{+}$ & $\mathrm{K}^{+}$ & $\mathrm{Cl}^{-}$ & $\mathrm{SO}_{4}^{2-}$ \\
\hline World average (unpolluted) & 13.4 & 3.4 & 5.2 & 1.3 & 5.8 & 6.6 \\
\hline Rain Creek (R) & $11.7 \pm 3$ & $2 \pm 0.6$ & $9.6 \pm 2.5$ & $0.3 \pm 0.0$ & $1.3 \pm 0.3$ & $7.2 \pm 2$ \\
\hline West Fork of the Mogollon (WFM) & $10 \pm 3.5$ & $2 \pm 1.5$ & $9.4 \pm 3.3$ & $0.5 \pm 0.1$ & $1.2 \pm 0.5$ & $6.9 \pm 1.8$ \\
\hline Mogollon Creek (M) & $11.5 \pm 4$ & $3.5 \pm 1.2$ & $10 \pm 2.8$ & $1.6 \pm 1.2$ & $2.5 \pm 1.3$ & $9.8 \pm 3.6$ \\
\hline West Fork of the Gila (WFG) & $13.9 \pm 4$ & $3.1 \pm 0.4$ & $11.6 \pm 3$ & $1.3 \pm 0.2$ & $1.5 \pm 0.1$ & $4.9 \pm 1.8$ \\
\hline Middle Fork of the Gila (MFG) & $18 \pm 3.6$ & $4.1 \pm 1.4$ & $29.4 \pm 14$ & $2.4 \pm 1.5$ & $9.4 \pm 7.2$ & $14 \pm 5.6$ \\
\hline East Fork of the Gila (EFG) & $22 \pm 2.1$ & $4.5 \pm 1.3$ & $29 \pm 7.3$ & $1.7 \pm 0.6$ & $17 \pm 8.7$ & $14 \pm 4.3$ \\
\hline Gila downstream of the forks union (GU) & $19 \pm 2.8$ & $4.2 \pm 1.6$ & $23.6 \pm 7$ & $1.9 \pm 0.7$ & $10.8 \pm 7$ & $11.2 \pm 4$ \\
\hline Gila near Gila (GG) & $22 \pm 3.6$ & $5.5 \pm 0.7$ & $31 \pm 10.4$ & $1.9 \pm 0.3$ & $14.3 \pm 8$ & $24.6 \pm 9$ \\
\hline Gila at Birds Sanctuary (GBS) & $33 \pm 7.7$ & $8 \pm 1.7$ & $35 \pm 8.8$ & $2.1 \pm 0.3$ & $12.5 \pm 5$ & $35.1 \pm 5$ \\
\hline
\end{tabular}

${ }^{\mathrm{a}}$ From Berner and Berner [1987]. Study sites are sorted by drainage size, and data are shown in $\mathrm{mg} / \mathrm{L}$. 

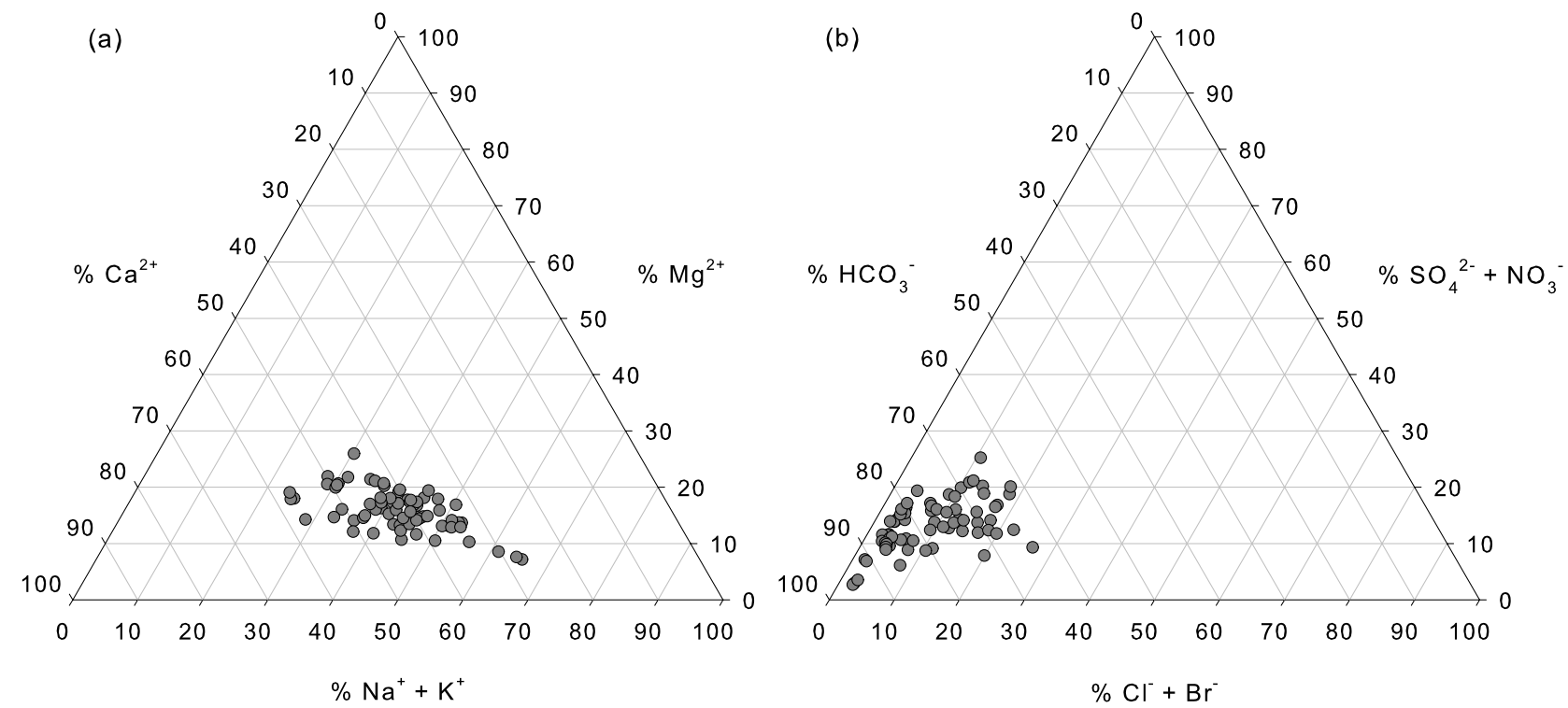

Figure 3. Piper diagram of the study sites in the Gila River from 1 May 2006 to 1 January 2007. Data points are expressed in percent of milliequivalents per liter of the cations $\mathrm{Ca}^{2+}, \mathrm{Mg}^{2+}, \mathrm{Na}^{+}+\mathrm{K}^{+}$(a) and anions $\mathrm{Cl}^{-}+\mathrm{Br}^{-}, \mathrm{SO}_{4}{ }^{2-}+\mathrm{NO}_{3}^{-}$and $\mathrm{HCO}_{3}^{-}(\mathrm{b})$.

ity in most anions and cations, except $\mathrm{PO}_{4}^{3-}$ and $\mathrm{NH}_{4}^{+}$. The geological units 'Alluvium', 'Piedmont alluvial deposits', 'Gila group, formation or conglomerate' and 'Basaltic to andesitic lava flows' were the best predictors of $\mathrm{Cl}^{-}, \mathrm{Br}^{-}$, $\mathrm{NO}_{3}^{-}, \mathrm{Na}^{+}, \mathrm{Ca}^{2+}$ and $\mathrm{Mg}^{2+}$, with $\mathrm{R}^{2}$ ranging from 0.50 to $0.95(\mathrm{P}<0.01)$. The strength of the relationships between drainage size and geology with the concentration of most chemical parameters was stronger during baseflow than during monsoonal conditions (Table 3). However, the differences in statistical strength between baseflow and monsoonal periods were not significant for all the analyzed landscape features. Thus, the strength of the relationship between the geological units 'Alluvium' and 'Gila group, conglomerate' and water chemistry did not differ significantly between baseflow and monsoon periods. However, this was not the case for most geological units or drainage size, which had a stronger influence on the water chemistry during baseflow conditions. The soil type that most contributed to spatial variability in chemical composition was a typical Argid soil 'Lithic Argiustolls, clayey, Montmorillonitic, mesic', while the Ustisol soil type 'Lithic Ustochreps, loamy skeletal, mixed, mesic' was among the few landscape cover features that explained part of the variability in $\mathrm{PO}_{4}^{3-}$ and $\mathrm{NH}_{4}^{+}\left(\mathrm{R}^{2}\right.$ of 0.82 and 0.67 , respectively, $\mathrm{P}<0.01$ ).

[19] Compared with the landscape cover features at the subcatchment scale, landscape cover features within the 100 $\mathrm{m}$ riparian ecotone explained lesser variation in water chemistry concentrations. However, the riparian ecotone was the best predictor for sediment related factors in stream channels such as TSS, as well as for $\mathrm{PO}_{4}^{3-}$. Thus, the best predictor for $\mathrm{PO}_{4}^{3-}$ differences among sites was the Ustisol soil type 'Lithic Ustochreps, loamy skeletal, mixed, mesic' $\left(\mathrm{R}^{2}=0.70, \mathrm{P}<0.01\right)$ followed by the geological unit 'Upper middle Tertiary rhyolitic lavas and local tuffs' $\left(\mathrm{R}^{2}=0.50\right.$, $\mathrm{P}<0.01$ ), both at the ecotonal level. Similarly, the best predictor for TSS was the geological unit 'Silicic to intermediate volcanic rocks' $\left(\mathrm{R}^{2}=0.84, \mathrm{P}<0.01\right)$ followed by the Argid soil developed in stony material and with abun- dant montmorillonitic clays 'Typic Argiborolls, fine, mixed' $\left(\mathrm{R}^{2}=0.79, \mathrm{P}<0.01\right)$, both at the ecotonal level. In contrast with geology and soil types, vegetation types were poor predictors of chemical composition and of TSS at the subcatchment or riparian scales.

\subsection{Temporal Variability in Surface Water Chemistry}

[20] In the Gila River network, changes in discharge involved changes in the concentrations and loads of most ions. However, the effect of discharge on the various major ions was not equivalent. Thus, most anions and cations, such as $\mathrm{Cl}^{-}$, showed a negative relationship with discharge (Figure $4 \mathrm{a}$ ), but $\mathrm{PO}_{4}^{3-}$ showed a positive relationship (Figure 4b). These relationships were also reflected in terms of loads, so that most anions, such as $\mathrm{Cl}^{-}$, increased just one order of magnitude, while $\mathrm{PO}_{4}^{3-}$ showed an increase of more than two orders of magnitude. In contrast, only $\mathrm{Na}^{+}$ among the cations showed a significant relationship with

Table 3. Paired-Samples $T$ Test Between $R_{\text {baseflow }}$ and $R_{\text {monsoon }}$ With Each Solute as Pair ${ }^{\mathrm{a}}$

\begin{tabular}{lcccc}
\hline \multicolumn{1}{c}{ Independent Variable } & Mean & T-Statistic & df & $\begin{array}{c}\text { Sig. } \\
\text { (2-Tailed) }\end{array}$ \\
\hline Coniferous and mixed woodland & 0.148 & 1.299 & 9 & 0.226 \\
Mancos Shale & 0.178 & 2.817 & 9 & 0.020 \\
Permian rocks & 0.134 & 2.083 & 9 & 0.067 \\
Paleozoic rocks & 0.178 & 2.817 & 9 & 0.020 \\
Alluvium & 0.055 & 0.684 & 9 & 0.511 \\
Gila group, conglomerate & 0.600 & 0.617 & 9 & 0.552 \\
Tertiary intrusive rocks of & 0.165 & 2.655 & 9 & 0.026 \\
$\quad$ intermediate Si composition & & & & \\
Lower middle Tertiary rhyolitic lavas & 0.131 & 2.037 & 9 & 0.072 \\
Basaltic to andesitic lava flows & 0.128 & 1.891 & 9 & 0.091 \\
Upper middle Tertiary rhyolitic lavas & -0.184 & -1.512 & 9 & 0.165 \\
Upper middle Tertiary pyroclastic rocks & 0.107 & 1.979 & 9 & 0.079 \\
Drainage size & 0.768 & 1.496 & 9 & 0.008 \\
\hline
\end{tabular}

${ }^{\mathrm{a}}$ Mean difference, t-statistic, degrees of freedom, and significance are indicated for different landscape features (significant $\mathrm{P}$ values imply $\left.\mathrm{R}_{\text {baseflow }}>\mathrm{R}_{\text {monsoon }}\right)$. The used solutes were $\mathrm{Na}^{+}, \mathrm{Ca}^{2+}, \mathrm{Mg}^{2+}, \mathrm{K}^{+}, \mathrm{Cl}^{-}$, $\mathrm{Br}^{-}, \mathrm{NO}_{3}{ }^{-}, \mathrm{SO}_{4}{ }^{2-}$, and $\mathrm{PO}_{4}{ }^{3-}$. 


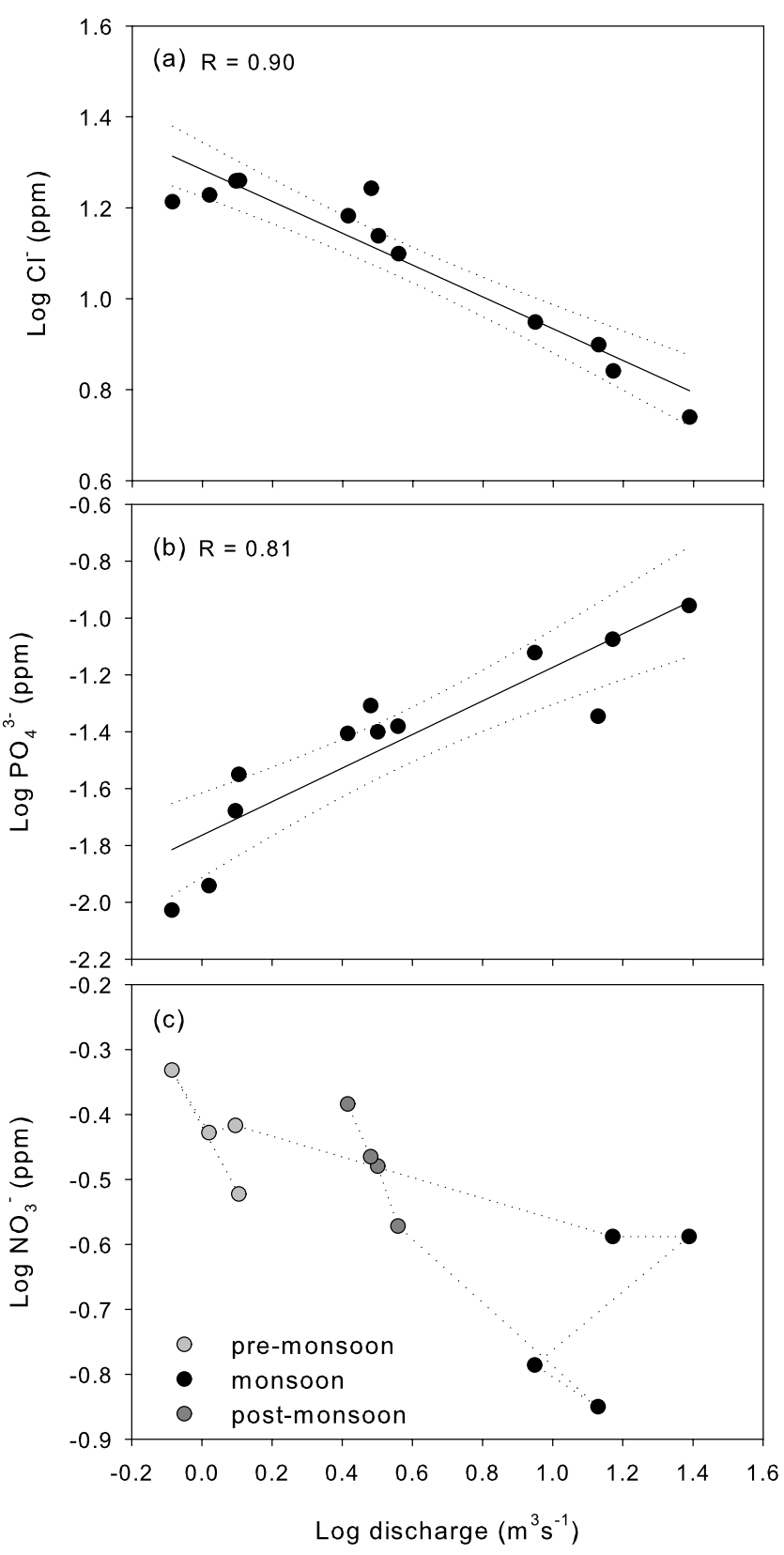

Figure 4. Linear regressions between daily discharge and $\mathrm{Cl}^{-}$concentration (a) and $\mathrm{PO}_{4}{ }^{3-}$ concentration (b) in the Gila River (GG and GBS sites). Dotted lines indicate 95\% confidence intervals.

discharge. All significant relationships between major ions and discharge were linear except for $\mathrm{NO}_{3}^{-}$, which showed a clockwise hysteresis pattern, with higher values of $\mathrm{NO}_{3}^{-}$ during the rising limb of the hydrograph with respect to the falling limb (Figure 4c). The relatively higher increase of $\mathrm{PO}_{4}^{3--}$ with respect to inorganic nitrogen $\left(\mathrm{NO}_{3}^{-}+\mathrm{NH}_{4}^{+}\right)$with increasing discharge caused a decrease in the inorganic $\mathrm{N}: \mathrm{P}$ ratio. The decrease in the $\mathrm{N}: \mathrm{P}$ ratio was maximal in the largest system (GBS), where the N:P ratio changed from 60 to 3 and showed a significant relationship with discharge $\left(\mathrm{R}^{2}=0.86, \mathrm{P}<0.01\right)$.

[21] Correlation analyses between different chemical solutes revealed strong linear relationships between $\mathrm{Cl}^{-}$and
$\mathrm{SO}_{4}^{2-}$ in the MFG, EFG, GU and GG. The strength of the relationship was strongest in middle tributaries such as the MFG $\left(R^{2}=0.96, P<0.01\right)$, while it was weaker in the main stem of the Gila River $\left(\mathrm{R}^{2}=0.84, \mathrm{P}<0.01\right)$ (Figure 5). Similar linear relationships between solutes were observed with $\mathrm{Br}^{-}, \mathrm{Na}^{+}, \mathrm{Mg}^{2+}$ and $\mathrm{Ca}^{2+}$. However, a temporal pattern was common in all these linear relationships, going from the top right corner (preflood baseflow conditions) to the bottom left corner (monsoonal floods) and back to the top right (postflood baseflow conditions). Meteoric water and geothermal water lay on the extremes of these linear relationships between $\mathrm{Cl}^{-}$and $\mathrm{SO}_{4}^{2-}$ (Figure 5). Meteoric and geothermal waters were considered as end members in the EMMA, which indicated that the contribution of geothermal springs ranged from $1 \pm 2.5 \%$ during the monsoons to around $20 \pm 10 \%$ during baseflow in the MFG and in the Gila River (GU and GG). In the $\mathrm{MFG}$, the $\mathrm{Cl}: \mathrm{Br}$ ratio ranged from values above 1500 to values below 500 . However, the range was only between 400 and 700 in larger systems, regardless of a similar range in $\mathrm{Cl}^{-}$concentration. In both cases, higher values corresponded with baseflow conditions and lower values with monsoonal rains. In clear contrast with the middle and large systems, there were no clear temporal patterns in the $\mathrm{Cl}: \mathrm{Br}$ ratio in the smaller systems. The longitudinal sampling along the mainstem Gila River revealed significant relationships between several conservative ions such as $\mathrm{Mg}^{2+}$ and $\mathrm{Ca}^{2+}$ during baseflow conditions (Figure 6). Thus, the concentrations of both cations increased at a similar rate as the water was traveling downstream and the projection of the linear relationship for these cations pointed to the origin. This spatial trend was not evident during high flow conditions along the $120 \mathrm{~km}$ of the Gila River.

[22] The first 2 components of the PCA unrotated solution explained $75 \%$ of the total variance $(57 \%$ by the first component and $18 \%$ by the second component). Temporal variability in each site during the whole study period was

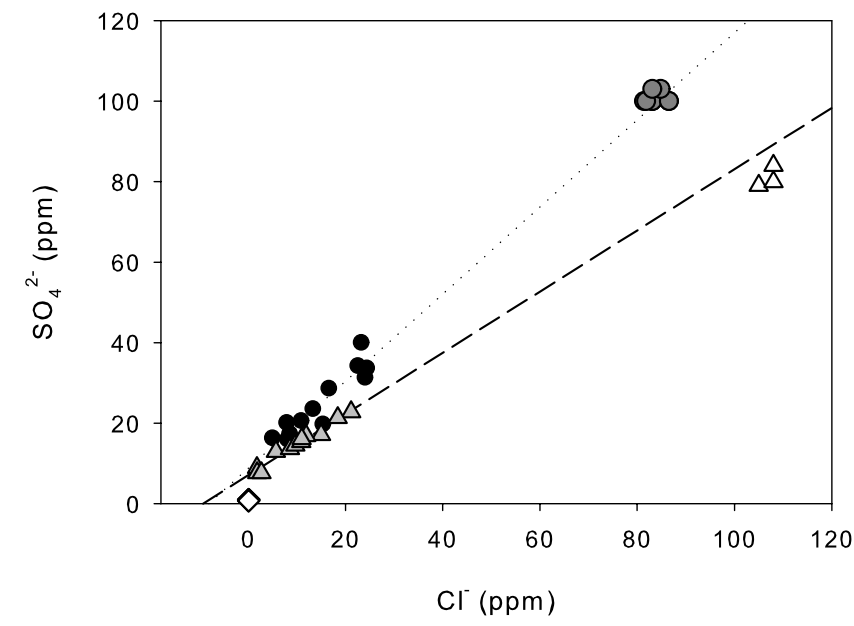

Figure 5. Concentrations of $\mathrm{Cl}^{-}$and $\mathrm{SO}_{4}{ }^{2-}$ in: Middle Fork of the Gila (grey triangles), hot springs in the Middle Fork of the Gila (white triangles), Gila near Gila (black circles), hot springs upstream of the Gila near Gila (grey circles) and in meteoric water (white diamonds) (National Atmospheric Deposition Program). Dotted lines indicate 95\% confidence intervals. 


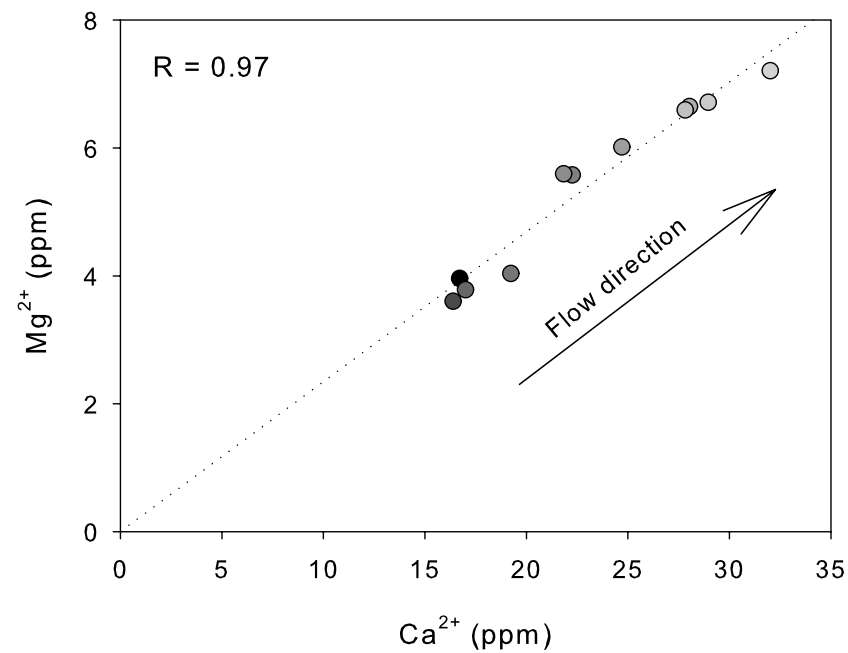

Figure 6. Linear regression between concentrations of $\mathrm{Ca}^{2+}$ and $\mathrm{Mg}^{2+}$ along the Gila River (from WFG to GBS). Grey tonalities range from dark (headwaters) to light (downstream).

summarized by the standard deviation of the factor scores of the first principal component, which was strongly related to drainage size $\left(\mathrm{R}^{2}=0.79, \mathrm{P}<0.01\right)$ (Figure 7$)$. This pattern between drainage size and temporal variability indicates that larger systems were more variable in the Gila, and was mainly caused by temporal variability in concentrations of $\mathrm{Cl}^{-}, \mathrm{SO}_{4}^{2-}, \mathrm{NO}_{3}^{-}$and $\mathrm{Br}^{-}$. Spatial variability between sites for each sampling date was summarized by the standard deviation of the factor scores of the first principal component. The spatial heterogeneity of surface water chemistry was higher during baseflow conditions, so that differences between study sites were maximal during baseflow conditions and minimal during monsoonal rains (Figure 8).

\section{Discussion}

\subsection{Spatial Variability in Surface Water Chemistry}

[23] Concentrations of solutes were found to vary greatly between subcatchments, suggesting that considerable spatial complexity results from the influence of a variety of biogeochemical and transport processes. Geology at the subcatchment scale explained a majority of the spatial variability in most anions and cations, but landscape features had less explanatory power for nutrients relative to biologically conservative solutes. In a study of 101 catchments in New Zealand, between 60 and $80 \%$ of the variance in major ions was accounted for by landscape features, including geology and land use [Close and Davies-Colley, 1990]. However, landscape features accounted for only about $50 \%$ of the variance in $\mathrm{NH}_{4}^{+}$and $\mathrm{PO}_{4}^{3-}$ [Close and Davies-Colley, 1990]. Similarly, Johnson et al. [1997] reported weak relationships between land use or geology and $\mathrm{NH}_{4}^{+}$or $\mathrm{PO}_{4}^{3-}$ concentrations. These results parallel those from the Gila in that less variability in $\mathrm{NH}_{4}^{+}$or $\mathrm{PO}_{4}^{3-}$ concentrations was explained by geology or land cover with respect to other major ions.

[24] This decoupling between landscape features and nutrients such as $\mathrm{NH}_{4}^{+}$or $\mathrm{PO}_{4}^{3-}$ may be caused by biological control in headwater streams [e.g., Mulholland, 1992; Mulholland and Hill, 1997; Van Herpe and Troch, 2000;

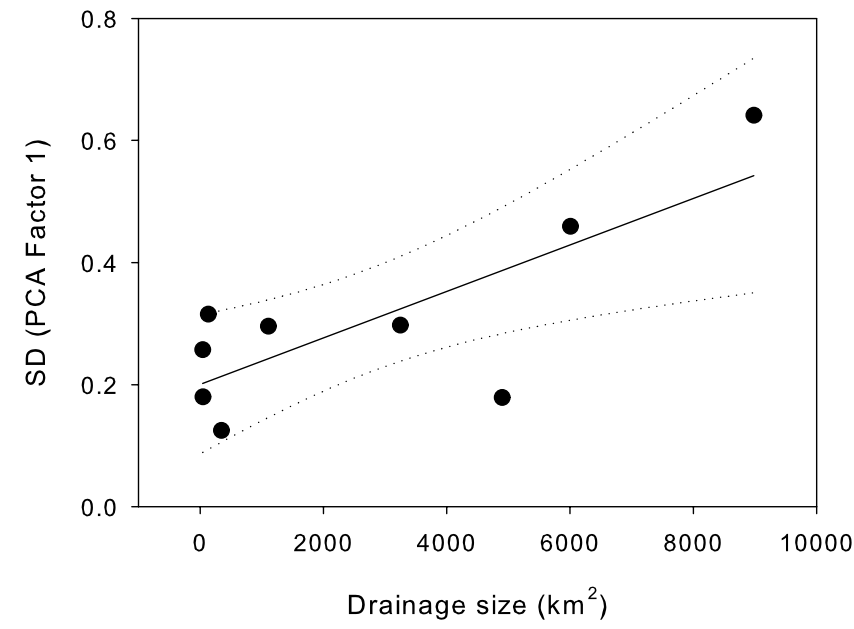

Figure 7. Linear regression between the standard deviation (SD) for each site of the score values of the first PCA component and drainage size in $\mathrm{km}^{2}$. Dotted lines indicate $95 \%$ confidence intervals.

Peterson et al., 2001]. In a comparative ${ }^{15} \mathrm{~N}$-tracer study of inorganic nitrogen dynamics in headwater streams, Peterson et al. [2001] showed that headwater streams typically export less than half of the input of dissolved inorganic nitrogen from their watersheds during seasons of high biological activity. The stronger statistical relationships between these nutrients and land cover variables during periods of lowest capacity for instream biological uptake (postflood periods) supports the hypothesis of decoupling between land cover features and nutrient concentrations as a result of biological control during baseflow conditions.

[25] Geological characteristics at the subcatchment scale and drainage size, rather than elevation, slope, vegetation, soil or precipitation, explained chemical differences between sites across spatial scales. In contrast with major conservative ions, sediment-associated factors in stream channels, namely $\mathrm{PO}_{4}^{3-}$ and TSS, were accounted for by ecotonal data, similar to that reported by Johnson et al. [1997]. Although the functions that the riparian ecotone play in moderating chemical composition of streams are well described, the relative influence of the riparian zone

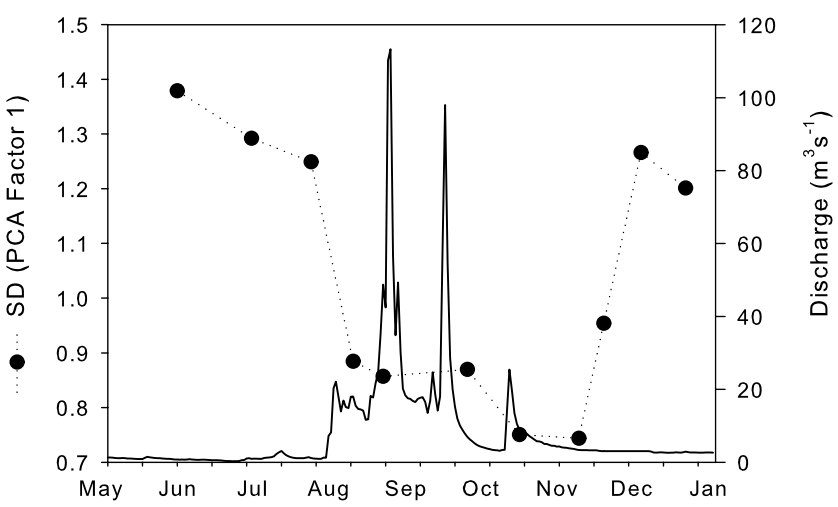

Figure 8. Standard deviation (SD) for each sampling date of the score values of the first PCA component and discharge in the Gila River (data from USGS gauging station 09430500). 
versus the catchment on mean water chemistry is known to be variable and not well understood [Richards et al., 1996; Hunsaker and Levine, 1995; Johnson et al., 1997; Gergel et al., 1999; Strayer et al., 2003]. For example, Richards et al. [1996] reported that landscape factors within the $100 \mathrm{~m}$ ecotone were sufficient for predicting most water chemistry concentrations, as well as sediment-related factors in stream channels. In contrast, Hunsaker and Levine [1995] found that 200 and $400 \mathrm{~m}$ buffer strips explained a smaller proportion of the total variance in water chemistry than whole catchments.

[26] This apparent contradiction has been proposed to depend on the scale of the watershed considered [Gergel et al., 1999]. Thus, riparian vegetation plays a significant role in small agricultural catchments [Debano and Schmidt, 1990; Schlosser and Karr, 1981]. In contrast, catchment land uses were as important as riparian land uses in larger watersheds [Omernik et al., 1981; Gergel et al., 1999; Stendera and Johnson, 2006]. For example, Stendera and Johnson [2006] showed that only $6 \%$ of the variation in surface water chemistry was explained by local factors alone. In the Gila, the lesser relevance of vegetation with respect to similar studies in more humid areas also should be noted [Hunsaker and Levine, 1995; Gergel et al., 1999; Stendera and Johnson, 2006]. These differences may be caused by the dispersed and heterogeneous character of the vegetation in this semiarid catchment. Supporting these results, Strayer et al. [2003] argued that the spatial perspective (whole catchment, riparian ecotone or local) most effective at predicting ecological response variables varied across response variables, apparently in concordance with mechanisms that control each of these variables.

\subsection{Temporal Variability in Surface Water Chemistry}

[27] Solute concentrations in streams of the Gila basin were influenced by discharge, particularly in the case of anions like $\mathrm{Cl}^{-}, \mathrm{SO}_{4}^{2-}$ and $\mathrm{PO}_{4}^{3-}$. The concentration of most anions decreased with discharge, while $\mathrm{PO}_{4}^{3-}$ concentration increased two fold. Among cations, only $\mathrm{Na}^{+}$showed a significant relationship with discharge. In a study of the impact of soil and groundwater heterogeneity on surface water chemistry in an upland catchment, Stutter et al. [2006] reported no significant relationships between discharge and either $\mathrm{SO}_{4}^{2-}$ or $\mathrm{NO}_{3}^{-}$at any sites of different drainage size within the same catchment. These authors also reported that concentrations of basic cations decreased with increasing discharge, and among them, $\mathrm{Ca}^{2+}$ showed the strongest relationship with discharge, while $\mathrm{K}^{+}$was unrelated to discharge. Similarly, Buffam et al. [2007] reported a decrease in base cation concentration during spring floods (mean decrease of $58 \%$ ). In the Gila, the positive relationship between discharge and $\mathrm{PO}_{4}^{3-}$ was likely caused by rapid surface flows of water that enhanced erosion and desorption and, therefore, transport of $\mathrm{PO}_{4}^{3-}$, which is largely bound to particulate matter [Dillon and Kirchner, 1975; Grobler and Silberbauer, 1985].

[28] The linear relationship between concentrations of two conservative solutes $\left(\mathrm{Cl}-\right.$ and $\left.\mathrm{SO}_{4}^{2-}\right)$ in a suite of samples in two forks of the Gila (MFG and EFG), and in the Gila River sites (GU, GG and GBS) during the study period suggested that these anions may be the products of mixing of two water sources with different chemical composition.
In such cases of binary mixing, the concentration of conservative solutes was controlled by the relative contribution of ground water and surface runoff. The fact that data from the Gila River scatter both above and below the mixing line indicates that there were other water sources influencing chemical composition in the larger systems (GG or GBS) (Figure 5), while there were no patterns of binary or ternary mixtures in the smaller streams (R, M, WFM and WFG). The strong fit of meteoric and geothermal water in linear projections of binary mixings shown in Figure 5 reveal that predominant water sources in the Gila River were meteoric and geothermal water. Temporal patterns in the $\mathrm{Cl}: \mathrm{Br}$ ratio support the hypothesis of a geothermal water source with a significant contribution during baseflow conditions. However, meteoric water was always the major source to the Gila River, with a relative contribution ranging from 75 to $98 \%$.

[29] The shift in the relative contribution of each water source was also reflected in the lesser influence of geology on water chemistry during the monsoonal floods, suggesting that seasonal changes in hydrologic routing and water sources (e.g., overland flow versus groundwater sources) have important consequences for stream chemistry. Data reflect a faster and predominantly surface hydrologic connection between the catchment and the rivers during the monsoonal period that was not present during baseflow conditions. In addition, different processes or processes operating at different spatial and temporal scales influenced water chemistry in the monsoonal period compared with baseflow conditions. Supporting these results, other studies have shown that processes operating at different spatial and temporal scales influence water chemistry in different periods with differing levels of hydrological connection between catchment and river chemistry [Williams et al., 1993; Johnson et al., 1997; Jordan et al., 1997; Van Herpe and Troch, 2000].

[30] Lower variation in the $\mathrm{Cl}: \mathrm{Br}$ ratio with respect to the high variation in $\mathrm{Cl}^{-}$concentration in the larger systems appears to be the product of evaporative concentration during baseflow conditions and dilution during monsoonal floods. The effect of evaporative concentration during baseflow conditions was obvious in the longitudinal concentration trends of several conservative ions such as $\mathrm{Mg}^{2+}$ and $\mathrm{Ca}^{2+}$. Thus, as water is lost, the concentration of these conservative ions in solution rose in such a way that their ratios remained constant and the dilution line was directed towards the origin [Faure, 1998]. Clear effects of evapotranspiration suggest that there were no major inputs of ground water along the Gila River and partly explain the amplified variation of chemical composition in downstream sites. Therefore, most of the runoff during baseflow conditions was generated at the intermediate to higher elevations of the catchment. The scarcity of protective vegetation cover, high temperatures and low antecedent soil moisture at low altitudes combine to produce maximum rates of evapotranspiration in lowlands and, therefore, low contribution to baseflow, as well as negligible runoff when compared with headwaters [Grimm et al., 1997].

\subsection{Scale-Dependent Patterns of Stream Water Chemistry}

[31] Appropriate consideration of scale is essential for interpreting ecological data [Wiens, 1989]. Scale and het- 
erogeneity in space and time have been acknowledged as important issues in ecology for many years [Pielou, 1977; O'Neill et al., 1986; Levin, 1992; Belovsky et al., 2004; Hewitt et al., 2007]. This research provides evidence for scale dependencies in the chemical composition of semiarid streams. In the Gila River basin, we found that temporal variability in stream chemistry increased with the area of the drainage unit considered. These differences in temporal pattern observed among catchments likely reflect changes in the relative contribution of water sources, as well as the differential effect of dilution and concentration, with downstream position in the broader channel network. Indeed, this suggests that there are thresholds in drainage size, past which a different set of processes emerge to generate temporal pattern in stream chemistry. Thus, source areas in the headwaters showed a uniform chemical signature, which was amplified in middle order tributaries because of the contribution of geothermal springs. Further downstream, concentration of solutes by evaporative losses along the river played a major role in amplifying the chemical signature. There was a clear scale-dependency in the temporal variability of chemical composition in the Gila River network, but this pattern may be continuous only within the spatial range of the study and not extend to broader scales. Nevertheless, chemical conditions experienced by biota are much more variable in larger systems in the Gila.

[32] In contrast with results of this study, Stutter et al. [2006] summarized an inverse relationship between spatial scale and temporal variability in surface water chemistry, so that larger systems were less variable than smaller systems. These authors attributed lower temporal variability of larger systems to the mixture of individual signatures of upstream subcatchments. Also, in contrast with the results in the Gila catchment, Temnerud and Bishop [2005] reported an inverse relationship between spatial scale and variability in a study of the spatial variation of chemical composition of streams in two boreal catchments in Sweden. A broader insight of this research is the temporal component of these scaling issues, as monsoonal rains clearly influenced the scaling component of the chemical composition of streams in the Gila catchment. Thus, increased surface runoff during monsoonal rains produces a decrease of differences across spatial scales. In contrast, Mulder et al. [1995] found that increased runoff produced more spatial variability in chemical composition of streams across the Birkenes and Ingabekken catchments (Norway), because compositions were controlled by soil-specific runoff chemistry. Similarly, Buffam et al. [2007] reported that spatial variability of base cations among fifteen sites in Krycklan, a fourth-order stream network in northern Sweden, increased slightly with high flow. Therefore, patterns observed in the Gila River network may be characteristic of arid and semiarid rivers, where evapotranspiration further modifies differences in chemical composition of streams across scales, and where rainfall pulses homogenize rather than differentiate the chemical composition of streams across scales.

\subsection{Conclusions and Implications}

[33] Growing evidence indicates that major impacts of global warming on streams are likely to be experienced through increased temporal variability in rainfall and as changes in the frequency of extreme events with higher interannual variation [Whetton et al., 1993; Fowler and Hennessy, 1995; Frei et al., 1998]. Temporal variability in rainfall patterns in xeric regions as a result of climate change may have profound effects on river network integrity and on water chemistry. Longer temporal periods with no rainfall will desiccate most of the Gila River network and restrict flow permanence to middle order tributaries of the headwaters, with likely river network fragmentation. More extreme chemical conditions, as well as temperature increases, in larger systems will likely occur during baseflow conditions.

[34] Many drainage systems outside the southwestern United States also have strongly seasonal precipitation/ hydrologic regimes, and therefore may show similar spatial and temporal patterns of stream chemistry to those observed in the Gila (the Gila may represent an end-member along a mesic-xeric continuum). Further, given that different patterns of stream chemistry are observed between mesic and xeric drainage networks (as described in the Discussion), climate changes could potentially push systems toward one of these end members (e.g., in the case of increasing drought frequency in what are currently mesic drainages.)

[35] Differences in scaling patterns in stream chemical composition between this study and those from mesic systems [Mulder et al., 1995; Temnerud and Bishop, 2005; Stutter et al., 2006; Buffam et al., 2007] reflect general differences between mesic and xeric basins. The hydrologic sensitivity to rainfall, differences in contributing areas between high and low flow periods, and the potential for large evaporative losses during low flow periods are features that make drainage systems in drier/more seasonal climates behave differently than their mesic counterparts.

[36] Acknowledgments. John Craig, Laura Crossey, Sergi Sabater, Martha Schumann, Klement Tockner, Urs Uehlinger, and Dave Van Horn (in alphabetical order) assisted in the field or in the laboratory. The research was funded by a MEC-Fulbright fellowship of the Spanish Science and Education Ministry, the National Science Foundation (IGERT Freshwater Sciences Interdisciplinary Doctoral Program, DGE 9972810), the University of New Mexico, and The Nature Conservancy.

\section{References}

Adams, D. K., and A. C. Comrie (1997), The North American monsoon, Bull. Am. Meteorol. Soc., 78(10), 2197-2213.

Allan, J. D. (1995), Stream Ecology: Structure and Function of Running Waters, 388 pp., Kluwer, Netherlands.

Allan, J. D., and L. B. Johnson (1997), Catchment-scale analysis of aquatic ecosystems, Freshwater Biol., 37, 107-111.

Allan, J. D., D. L. Erickson, and J. Fay (1997), The influence of catchment land use on stream integrity across multiple spatial scales, Freshwater Biol., 37, 149-162.

American Public Health Association (APHA) (1998), Standard Methods for the Examination of Water and Wastewater, Washington, D. C.

Belovsky, G. E., et al. (2004), Ten suggestions to strengthen the science of ecology, Bioscience, 54, 345-348.

Bernal, S., A. Butturini, and F. Sabater (2006), Inferring nitrate sources through end member mixing analysis in an intermittent Mediterranean stream, Biogeochemistry, 81, 269-289.

Berner, E. K., and R. A. Berner (1987), The Global Water Cycle: Geochemistry and Environment, Prentice-Hall, Upper Saddle River, N. J.

Buffam, I., H. Laudon, J. Temnerud, C. M. Mörth, and K. Bishop (2007), Landscape-scale variability of acidity and dissolved organic carbon during spring flood in a boreal stream network, J. Geophys. Res., 112, G01022, doi:10.1029/2006JG000218.

Burns, D. A., J. J. McDonnell, R. P. Hooper, N. E. Peters, J. E. Freer, K. Kendall, and K. Beven (2001), Quantifying contributions to storm runoff through end member mixing analysis and hydrologic measurements at the Panola Mountain Research Watershed, Hydrol. Proc., 15, $1903-1924$ 
Christophersen, N., C. Neal, R. P. Hooper, R. D. Vogt, and S. Andersen (1990), Modelling streamwater chemistry as a mixture of soilwater endmembers - A step towards second-generation acidification models, $J$. Hydrol., 116, 307-320.

Close, M. E., and R. J. Davies-Colley (1990), Baseflow chemistry in New Zealand rivers 2. Influence of environmental factors, N. Z. J. Mar. Freshwater Res., 24, 343-356.

Debano, L. F., and L. J. Schmidt (1990), Potential for enhancing riparian habitats in the southwestern United States with watershed practices, For. Ecol. Manage., 33/34, 385-403.

Dillon, P. J., and W. H. Kirchner (1975), The effects of geology and land use on the export of phosphorus from watersheds, Water Res., 9, 135148.

Douglas, M. W., R. A. Maddox, K. Howard, and S. Reyes (1993), The Mexican monsoon, J. Clim., 6, 1665-1677.

Faure, G. (1998), Principles and Applications of Geochemistry, 600 pp., Prentice-Hall, Upper Saddle River, N. J.

Fowler, A. M., and K. J. Hennessy (1995), Potential impacts of global warming on the frequency and magnitude of heavy precipitation, Nat. Hazards, 11, 283-303

Frei, C., C. Schar, D. Luthi, and H. C. Davies (1998), Heavy precipitation processes in a warmer climate, Geophys. Res. Lett., 25, 1431-1434.

Gergel, S. E., M. G. Turner, and T. K. Kratz (1999), Dissolved organic carbon as indicator of the scale of watershed influence on lakes and rivers, Ecol. Appl., 9(4), 1377-1390.

Grimm, N. B., A. Chacon, C. N. Dahm, S. W. Hostetler, O. T. Lind, P. L. Starkweather, and W. W. Wurtsbaugh (1997), Sensitivity of aquatic ecosystems to climatic and anthropogenic changes: Basin and range American Southwest and Mexico, Hydrol. Proc., 11, 1023-1041.

Grobler, D. C., and M. J. Silberbauer (1985), The combined effect of geology, phosphate sources and runoff on phosphate export from drainage basins, Water Res., 19, 975-981.

Hewitt, J. E., S. F. Thrush, P. K. Dayton, and E. Bonsdorff (2007), The effect of spatial and temporal heterogeneity on the design and analysis of empirical studies of scale-dependent systems, Am. Nat., 169, 398-408.

Hunsaker, C. T., and D. A. Levine (1995), Hierarchical approaches to the study of water quality in rivers, Bioscience, 45, 193-203.

Hynes, H. B. N. (1975), The stream and its valley, Verh. Int. Ver. Theor. Angew. Limnol., 19, 1-15.

Johnson, L. B., C. Richards, G. E. Host, and J. W. Arthur (1997), Landscape influences on water chemistry in midwestern stream ecosystems, Freshwater Biol., 37, 193-208.

Jordan, T. E., D. L. Correll, and D. E. Weller (1997), Relating nutrient discharges from watersheds to land use and streamflow variability, Water Resour. Res., 33(11), 2579-2590.

Levin, S. A. (1992), The problem of pattern and scale in ecology, Ecology, 73, 1943-1967.

Mulder, J., N. Christophersen, K. Kopperud, and P. H. Fjeldal (1995), Water flow paths and the spatial distribution of soils as a key to understanding differences in stream water chemistry between three catchments (Norway), Water Air Soil Pollut., 81, 67-91.

Mulholland, P. J. (1992), Regulation of nutrient concentrations in a temperate forest stream: Roles of upland, riparian and in-stream processes, Limnol. Oceanogr., 37, 1512-1526.

Mulholland, P. J., and W. R. Hill (1997), Seasonal patterns in streamwater nutrient and dissolved organic carbon concentrations: Separating catchment flow path and in-stream effects, Water Resour. Res., 33(6), 1297 1306.
Omernik, J. M., A. R. Abernathy, and L. M. Male (1981), Stream nutrient levels and proximity of agricultural and forest land to streams: some relationships, J. Soil Water Conserv., 36, 227-231.

O’Neill, R. V., D. L. DeAngelis, J. B. Waide, and T. F. Allen (1986), A Hierarchical Concept of Ecosystems, Princeton Univ. Press, Princeton, N. J.

Osborne, L. L., and M. J. Wiley (1988), Empirical relationships between land use/cover patterns and stream water quality in an agricultural catchment, J. Environ. Manage., 26, 9-27.

Peterjohn, W. T., and D. L. Correll (1984), Nutrient dynamics in an agricultural catchment: Observations on the role of a riparian forest, Ecology, $65,1466-1475$.

Peterson, B. J., et al. (2001), Control of nitrogen export from watersheds by headwater streams, Science, 292, 86-90.

Pielou, E. C. (1977), Mathematical Ecology, John Wiley, New York

Richards, C., and G. E. Host (1994), Examining land use influences on stream habitats and macroinvertebrates: a GIS approach, Water Resour. Bull., 30, 729-738.

Richards, C., L. B. Johnson, and G. E. Host (1996), Landscape scale influences on stream habitats and biota, Can. J. Fish. Aquat. Sci., 53, $295-311$.

Schlosser, I. J., and J. R. Karr (1981), Riparian vegetation and channel morphology impact on spatial patterns of water quality in agricultural catchments, Environ. Manage., 5, 233-243.

Sheppard, P. R., A. C. Comrie, G. D. Packin, K. Angersbach, and M. K. Hughes (2002), The climate of the US Southwest, Clim. Res., 21, 219 238 .

Stendera, S., and R. K. Johnson (2006), Multiscale drivers of water chemistry of boreal lakes and streams, Environ. Manage., 38, 760-770.

Strayer, D. L., R. E. Beihley, L. C. Thompson, S. S. Brooks, C. Nilsson, G.Pinay, and R. J. Naiman (2003), Effects of land cover on stream ecosystems: Roles of empirical models and scaling issues, Ecosystems, 6, 407-423.

Stutter, M. I., L. K. Deeks, D. Low, and M. F. Billett (2006), Impact of soil and groundwater heterogeneity on surface water chemistry in an upland catchment, J. Hydrol., 318, 103-120.

Temnerud, J., and K. Bishop (2005), Spatial variation of streamwater chemistry in two Swedish boreal catchments: Implications for environmental assessment, Environ. Sci. Technol., 39, 1463-1469.

Van Herpe, Y., and P. A. Troch (2000), Spatial and temporal variations in surface water nitrate concentrations in a mixed land use catchment under humid temperate climatic conditions, Hydrol. Processes, 14, 2439-2455.

Whetton, P. H., M. R. Fowler, M. R. Haylock, and A. B. Pittock (1993),

Implications of climate change due to the enhanced greenhouse effect on floods and droughts in Australia, Clim. Change, 25, 289-317.

Wiens, J. A. (1989), Spatial scaling in ecology, Funct. Ecol., 3, 385-397.

Williams, M. K., A. D. Brown, and J. M. Melack (1993), Geochemical and hydrologic controls on the composition of surface water in a high-elevation basin, Sierra Nevada, California, Limnol. Oceanogr., 38(4), $775-$ 797.

V. Acuña, Department of Aquatic Ecology, Eawag, Überlandstrasse 133, CH-8600 Dübendorf, Switzerland. (vicenc.acuna@eawag.ch)

C. N. Dahm, Department of Biology, University of New Mexico, Albuquerque, NM 87131, USA. 